\title{
Structural models for analysis of reinforced concrete frame buildings with masonry infills
}

\section{Modelos estruturais para a análise de pórticos preenchidos com alvenaria em edifícios de concreto armado}
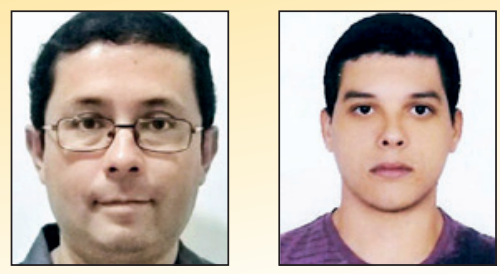

G. M. S. ALVA

alva gerson@yahoo.com.br https://orcid.org/0000-0002-2528-5757

G. A. MONTANDON a

guimontandon@hotmail.com https://orcid.org/0000-0002-4010-0933

\begin{abstract}
The behavior of single-storey, single-bay reinforced concrete infilled frame with masonry panel subjected to static horizontal load was studied using two structural models: i) equivalent strut model (ESM) and ii) model with two-dimensional finite elements for state stress plane (MEF). In the first model, an equivalent diagonal strut replaces masonry. The axial stiffness of this element is defined by evaluation of the equivalent diagonal width. In the second model, the infilled frame is modeling by two-dimensional finite elements, requiring the simulation of the sliding and separation between the wall surfaces and the reinforced concrete frame. Although equivalent strut models are more attractive for design, the formulas found in the literature to determine equivalent strut width provide very different values. In addition, most of these formulas ignore some parameters that may be important, such as beam flexural stiffness. For this reason, several numerical analysis were be carried out. The models simulated usual geometric and mechanical characteristics observed in reinforced concrete buildings. The results of the two-dimensional finite element modeling (by software ANSYS) were used as reference for the evaluation of the results provided by the equivalent strut model. The comparison of results allowed the assessment of the analytical expressions for evaluation of the equivalent diagonal width. Based on this assessment, a new expression is proposed for buildings with similar characteristics as analyzed in this paper. The results of numerical simulations with MEF models also allowed for an evaluation of stresses and the probable cracking pattern in infill walls.
\end{abstract}

Keywords: infilled frames, reinforced concrete frames, diagonal strut model, element finite method, structural analysis.

\section{Resumo}

Este trabalho tem como objetivo o estudo do comportamento de pórticos de edifícios de concreto armado preenchidos com alvenaria frente às ações horizontais, empregando-se dois modelos estruturais: i) modelo de diagonal equivalente (MDE) e ii) modelo com elementos finitos bidimensionais para estado plano de tensões (MEF). No primeiro modelo, a alvenaria é substituída por uma barra diagonal equivalente articulada. A rigidez axial dessa barra é definida com o cálculo da largura da diagonal equivalente. No segundo modelo, a alvenaria é modelada por elementos finitos bidimensionais, havendo a necessidade da simulação do deslizamento e da separação entre as superfícies da parede e do pórtico de concreto armado. Embora os modelos de diagonais equivalentes sejam mais atrativos para o projeto, as expressões analíticas da bibliografia internacional para o cálculo da largura da diagonal fornecem valores muito diferentes entre si. Além disso, a maioria dessas expressões desconsidera alguns parâmetros que podem ser importantes, tais como a rigidez à flexão da viga. Por essa razão, foram realizadas diversas simulações numéricas de pórticos isolados de concreto armado preenchidos com blocos cerâmicos com características geométricas e mecânicas usuais em edifícios de concreto armado. Os resultados da modelagem com elementos finitos bidimensionais (via programa ANSYS) foram utilizados como referência para a avaliação dos resultados fornecidos pelo modelo de diagonal equivalente. A comparação de resultados permitiu a aferição das expressões analíticas da bibliografia para o cálculo da largura diagonal equivalente e possibilitou a proposta de uma nova expressão aplicável a edifícios com geometrias similares aos modelos analisados. Os resultados das simulações numéricas com os modelos MEF também permitiram a avaliação das tensões solicitantes e do provável tipo de fissuração nas alvenarias.

Palavras-chave: pórticos preenchidos com alvenaria, pórticos de concreto armado, modelo de diagonal equivalente, método dos elementos finitos, análise estrutural. 


\section{Introduction}

Masonry walls in concrete building frame structures are used as sealing elements, which must meet basic requirements for watertightness, thermal and acoustic insulation. However, depending on the type of fixation with the main structure, infill walls can promote this structure's stiffening, performing as bracing walls; in this case also have a structural function.

With the masonry fixed in framed structure, when the building is subjected to lateral loads, the panels interact with the beams and columns, increasing the strength and the stiffness of the entire structure, called infilled frame structural system.

However, although fixed in the main structure, masonry panels usually have their stiffness disregarded in the building structura model. Masonry panels, in this case, appear in the structural analysis only as gravity (vertical) loads on the structural members on which they are supported (beams or slabs). In this case, it is seen that disregarding them as structural members is a practice in favor of safety. Nevertheless, according to Parsekian, Hamid and Drysdale [1], there are at least two reasons to show that this practice is not adequate. The first reason is that, in higher buildings, masonry infill walls provide a good contribution to the structure global stiffness compared to lateral loads. By disregarding them, the checks associated with the limit states of the structure would be more conservative. The second reason is that not always disregarding the stiffness of the infill walls leads to a more conservative design. According to these authors, the existence of infill walls at the some locations of the structure can significantly increase the stiffness of that part of the structure, which causes the internal forces distribution. Consequently, certain structural elements can be subjected to higher internal forces than the ones obtained in the structural model in which the infill wall as resistent member is ignored. In addition, a non-symmetrical distribution of the plan view walls can cause torsional moments and significantly change the internal forces distribution.

The most attractive model for considering the interaction between masonry and framed structure under lateral loads is the equivalent strut model (MDE). In this model, masonry is represented by a diagonal strut, whose cross section is defined by the wall thickness and the equivalent strut width. Models with more than one diagonal strut can be used to more accurately simulate the presence of the wall in the structural system. The equivalent strut width can be obtained by means of analytical expressions found in the international literature. Most of these expressions are presented and commented by Asteris et al. [2] for walls without openings. More recently, Morandi, Hak and Magenes [3] have compiled the analytical expressions in order to obtain the equivalent strut width, for both infill walls, without openings and for infil walls with openings.

Although there are several expressions in the literature to calculate the equivalent strut width, they provide very different results among them, which may inhibit the consideration of masonrystructure interaction in modeling (particularly in structural design). According to Araújo [4], the difference between the equivalent strut width values obtained with the various expressions can be higher than $100 \%$. Thus is necessary to be careful in the expression's choice so that a solution contrary to security is not obtained. It should be noted that most of these expressions disregard some parameters that may be important, such as flexural stiffness of the beam, the ratio between stiffness to beam and to column, as highlighted in Doudoumis [5], or the occurrence of columns with different cross sections in real buildings. Besides, it can be seen in the extensive international bibliography on the subject that there are no explicit indications of recommended expressions that provides more accurate results. In Brazil, no research is currently found to contribute to this.

The modeling of infilled frames can also be carried out by using of the Finite Element Method (FEM) in a plane stress state, which must consider the possibility of separation between the two surfaces (masonry infill wall and reinforced concrete frame) and the sliding between them. The results from this modeling can serve as a basis for the calibration of the equivalent strut width or for the assessment of the analytical expressions assigned to the calculation of the equivalent strut, as demonstrated in Doudoumis [5], Alva et al. [6] and Asteris et al. [7].

Several surveys are found in the international bibliography about the behavior of masonry infilled frames, the majority of which are dedicated to behavior under cyclic (seismic) loading. In Brazil, the number of research on the subject is reduced and more recent. Among the most recent research are those from Alvarenga [8], Santos [9], Tanaka [10], Madia [11], Silva [12] and Sousa [13]. In all of these studies, there was numerical simulation using FEM for simulating the stiffness of the infill walls subjected to lateral loads. The contribution of Alvarenga's investigations [8] deserves to be highlighted, due to the experimental results generated and the proposal of a new model to determine the strength capacity in strut-and-tie models. Regarding to Santos [9], Tanaka [10], Madia [11] and Sousa [13], single-storey reinforced concrete infilled frame were modeled, where the contact between infill wall and frame is simulated by springs. In these studies there are also application examples of the infilled frames modeling of entire structural systems. On the other hand, in Silva [12] the studies were focused on the effects of openings in walls on the structural behavior of infilled frames for checks at Serviceability Limite State. However, in none of the mentioned studies there are more detailed investigations on the differences between the several expressions from the literature for the calculation of the equivalent strut width nor on which expressions can provide better results in relation to the more precise models (FEM models or experimental models).

The central objective of this paper is the assessment of the main analytical expressions found in the specialized literature to calculate the equivalent strut width (MDE). For this purpose, numerical simulations of reinforced concrete frames with clay masonry infills were carried out with $2 \mathrm{D}$ finite elements for stress plane state (FEM), with contact's simulation among the masonry-frame interfaces. Numerical models have tried to represent beam spans and floor-to-floor distance commonly used in reinforced concrete buildings for different sizes of beams, columns and clay brick strength. The results provided by the FEM models served as reference for the verification of the analytical expressions presented in the literature. Finally, it is proposed a new expression applicable to buildings with geometries and mechanical properties (frame and masonry) similar to the models analyzed. 


\section{Equivalent strut model for analysis of infilled frames}

\subsection{Diagonal strut model (MDE)}

The concept of equivalent diagonal strut was presented by Polyakov [14]. From this concept, the wall is replaced by a pinjointed diagonal strut, as shown in Figure 1.

In the last two decades, important research [2, 3, 7, 15-26] are found in the international specialized bibliography regarding the development and application of strut equivalent models for structural analysis of infilled frames, for both single-strut models and multiple-strut models. It can be seen that important factors on the behavior of infilled frames were investigated: material nonlinearity (especially masonry), the strength capacity and possible failure modes, effects of cyclic loading (in particular seismic actions) and the effects of openings in infill walls.

\subsection{Equations for calculating equivalent diagonal strut}

For the complete definition of the equivalent strut model, it is necessary to know, besides the mechanical properties and the masonry thickness, the equivalent strut width.

Several analytical expressions are found in literature for the width of the equivalent diagonal strut calculating. However, the results obtained in each of these expressions can lead to differences among them of more than $100 \%[4,12]$. For this reason, a careful selection of the expression to be used is necessary, with a focus on structural safety. Table 1 contains the expressions analyzed in this paper. Figure 2 illustrates the geometric parameters used in

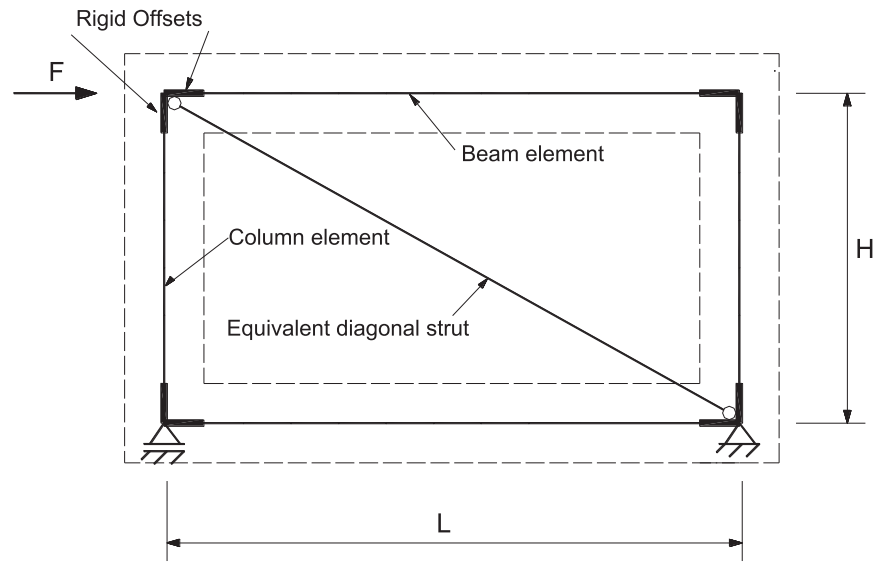

Figure 1

Static scheme of the investigated infill frame: MDE model

Adapted from SILVA [12]

these expressions.

In Table 1:

a - equivalent strut width;

$\alpha_{p}$ - length contact between masonry infill wall and column;

$\alpha_{v}$ - length contact between masonry infill wall and beam;

$\mathrm{D}$ - diagonal length of the masonry infill wall;

$\mathrm{E}$ - modulus of elasticity of the masonry infill wall;

$E_{p}-$ modulus of elasticity of the column;

$\mathrm{E}_{\mathrm{v}}$ - modulus of elasticity of the beam;

$\mathrm{h}$ - height of masonry infill wall;

$\mathrm{I}_{\mathrm{p}}$ - second moment of area of the column;

\section{Table 1}

Yield stress and viscosity of the pastes with varying contents of grinding dust (GD)

\begin{tabular}{|c|c|}
\hline Authors & Expressions \\
\hline Mainstone [27] & $\mathrm{a}=0,175 \cdot\left(\lambda_{H}\right)^{-0,4} \cdot D$ \\
\hline Hendry [28] & $\mathrm{a}=\frac{\sqrt{\alpha_{p}^{2}+\alpha_{v}^{2}}}{2} \quad \alpha_{v}=\frac{\pi}{\lambda_{p}} \leq l$ \\
\hline Liaw and Kwan [29] & $\mathrm{a}=\frac{0,95 \cdot \operatorname{sen}(2 \theta)}{2 \cdot \sqrt{\lambda_{H}}} \cdot D$ \\
\hline Decanini and Fantin [30]: uncracked & $\begin{array}{cc}\lambda_{H} \leq 7,85 & \lambda_{H}>7,85 \\
\mathrm{a}=\left(0,085+\frac{0,748}{\lambda_{H}}\right) \cdot D & \mathrm{a}=\left(0,130+\frac{0,393}{\lambda_{H}}\right) \cdot D\end{array}$ \\
\hline Decanini and Fantin [30]: cracked & 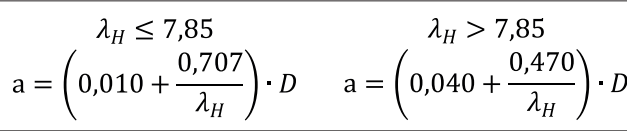 \\
\hline Paulay and Priestley [31] & $\mathrm{a}=\frac{D}{4}$ \\
\hline Durrani and Luo [32] & $\begin{array}{c}\mathrm{a}=\gamma \cdot \operatorname{sen}(2 \theta) \cdot D \\
m=6 \cdot\left(\frac{1+6 \cdot E_{V} \cdot I_{V} \cdot H}{\pi \cdot E_{P} \cdot I_{P} \cdot L}\right)\end{array}$ \\
\hline Chrysostomou and Asteris [22] & $\mathrm{a}=0,27 \cdot\left(\lambda_{H}\right)^{-0,4} \cdot D$ \\
\hline
\end{tabular}




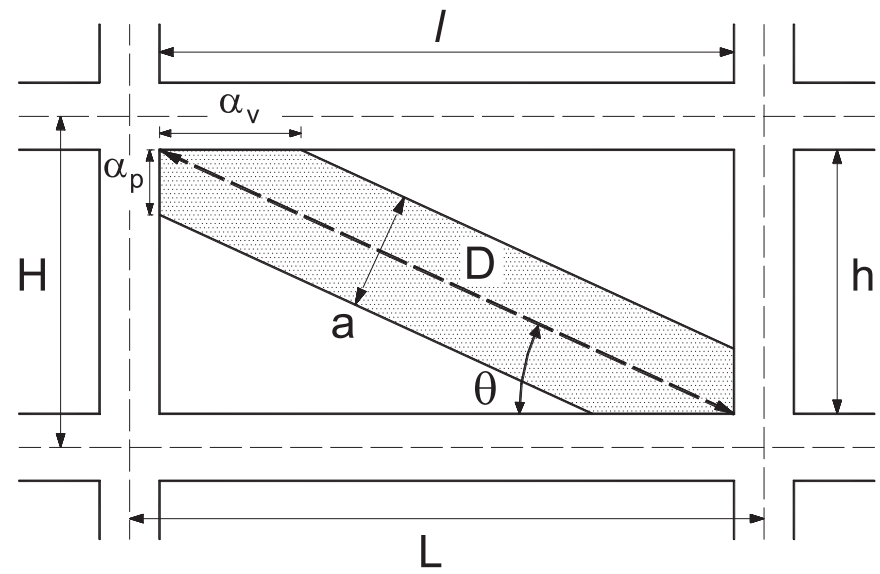

Figure 2

Dimensions used for calculating of equivalent strut width (a)

Adapted from SILVA [12]

$\mathrm{I}_{\mathrm{v}}$ - second moment of area of the beam;

$\mathrm{H}$ - height between beam axes (floor-to-floor distance);

I - length of the masonry infill wall;

$\mathrm{L}$ - distance between column axes;

$\mathrm{t}$ - wall thickness;

$\theta$ - angle whose tangent is the infill height-to-length aspect ratio (as shown in Figure 2).

The factor $\lambda_{H}$ (Equation 1) consists of multiplication of the relative panel-to-frame-stiffness parameter $\left(\lambda_{\mathrm{p}}\right)$ and the distance between the beams $(\mathrm{H})$ axes. This parameter consists of a dimensionless parameter (1/length unit) and expresses a stiffness ratio between the infill wall and the column. Most expressions use this factor to get the diagonal strut width. Hendry [28] expression, which uses the length contact between the frame members and the infill wall, the relative stiffness between the infill wall and the beam $\left(\lambda_{v}\right)$ is also used. Equations 2 and 3 contain the expressions for the calculation of mentioned relative stiffness parameters.

$\lambda_{H}=\lambda_{p} \cdot H$

$\lambda_{p}=\sqrt{\frac{E \cdot t \cdot \operatorname{sen}(2 \theta)}{4 \cdot E_{p} \cdot I_{p} \cdot h}}$

$\lambda_{v}=\sqrt{\frac{E \cdot t \cdot \operatorname{sen}(2 \theta)}{4 \cdot E_{v} \cdot I_{v} \cdot l}}$

It should be noted that the expression of Mainstone [27] is the most known among researchers in the infilled frames analysis, which is employed by FEMA 306 [34].

\section{Numerical modeling}

\subsection{Investigated models}

In this paper, 48 different models of single-storey reinforced concrete frames with clay masonry infills were studied. For all models, the height $\mathrm{H}$ (height between beam axes) was $3.0 \mathrm{~m}$. The beam and column widths was $20 \mathrm{~cm}$ and the wall thickness (t) was also equal to $20 \mathrm{~cm}$. The varied parameters were the height of the column cross section (same direction of longitudinal axis of the beam) according to Table 2, the height of the beam cross section with the length (span) (Table 3) and the compressive strength of the clay brick (Table 2). Efficiency factor of 0.5 (compressive strength of prisms/compressive strength of clay bricks) was assumed for the calculation of the masonry mechanical properties. Each parameter's code, for nomenclature purposes, is shown in Table 2. The model is the combination of a code for each parameter (eg B30V40P100, the compressive strength of the clay brick equal 3.0 $\mathrm{MPa}$, the height of the beam cross section equal to $40 \mathrm{~cm}$ and the height of the column cross section equal to $100 \mathrm{~cm}$ ).

According to Doudoumis [5] numerical simulations, ratio between the second moment area of the beam and the column $\left(\mathrm{I}_{\mathrm{V}} / \mathrm{I}_{\mathrm{p}}\right)$ causes a significant influence on the structural behavior of infilled frames. In the numerical simulations from [5], models with relationships $\left(I_{v} / I_{p}\right)$ between 0.25 and 8.0 were analyzed. On the other hand, in this paper, the variation spectrum of $\left(\mathrm{I}_{\mathrm{v}} / \mathrm{I}_{\mathrm{p}}\right)$ is between 0.064 and 8.0.

\subsection{Equivalent strut models - MDE}

The equivalent diagonal strut widths were obtained in two ways: i) by the analytical expressions from literature (Table 1); ii) obtained from the MDE models calibration according to the results provided by the FEM models, in which the lateral displacement equality between the two models was the calibration criterion.

In order to improve the MDE models results, in which beams and columns were simulated as plane frame members, the finite joint dimensions were considered by rigid offsets. The position of the rigid offsets was defined according to ABNT NBR 6118 [33] (see Figure 3 ). The values relating to second moment of area of the rigid sections were calibrated with FEM models results, whereby the

\section{Table 2}

Nomenclature used for the investigated models

\begin{tabular}{ccc}
\hline $\begin{array}{c}\text { Compressive } \\
\text { strength of the } \\
\text { clay brick } \\
\text { (MPa) }\end{array}$ & $\begin{array}{c}\text { Height of } \\
\text { the beam } \\
\text { cross section } \\
\text { (cm) }\end{array}$ & $\begin{array}{c}\text { Height of } \\
\text { the column } \\
\text { cross section } \\
\text { (cm) }\end{array}$ \\
\hline & & $30(\mathrm{P} 30)$ \\
$1.5(\mathrm{~B} 15)$ & $40(\mathrm{~V} 40)$ & $40(\mathrm{P} 40)$ \\
& $50(\mathrm{P} 50)$ & $50(\mathrm{P} 60)$ \\
& & $70(\mathrm{P} 70)$ \\
\hline $3.0(\mathrm{~B} 30)$ & $60(\mathrm{~V} 60)$ & $80(\mathrm{P} 80)$ \\
& & $90(\mathrm{P} 90)$ \\
& & $100(\mathrm{P} 100)$ \\
\hline
\end{tabular}

Table 3

Beam cross sections and respective spans

\begin{tabular}{cc}
\hline Beam (cm) & Span (m) \\
\hline $20 \times 40$ & 4.5 \\
$20 \times 50$ & 6.0 \\
$20 \times 60$ & 7.5 \\
\hline
\end{tabular}




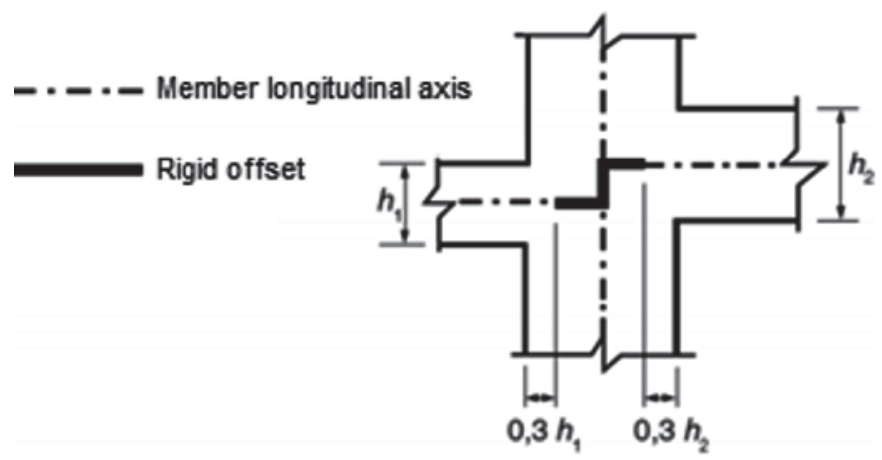

Figure 3

Schematization for considering of rigid offsets Font: ABNT NBR 6118 [33]

lateral displacement was the calibration criterion. This was performed for both models without the presence of walls.

The infilled frames, simulated with the strut equivalent models, were performed using program for linear analysis of plane frames.

\subsection{FEM models}

The numerical simulations using the Finite Element Method (FEM) were performed in the ANSYS software. The PLANE182 element from the program library was used for the modeling of both the concrete structure and the clay brick infill wall. This finite element, applicable for the plane stress state case, has four nodes, where each node has two degrees of freedom, which are the translations in the $X$ and $Y$ directions. These directions form the XY plane for analysis of the infilled frame. The discretization was based on a mesh refinement analized by Silva [12] Thus, finite elements of dimensions $5 \mathrm{~cm} \times 5 \mathrm{~cm}$ were defined for both the reinforced concrete frame and the infill panel (see Figure 4).

Regarding the contact problem, the CONTA172 / TARGE169 elements were used for the contact pair, which should allow the

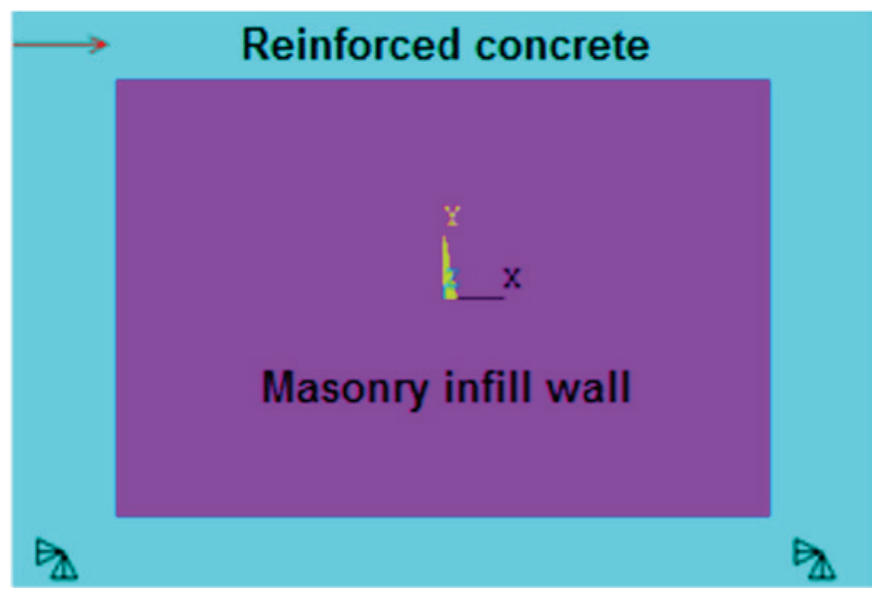

a simulation of sliding and separation between the surfaces of the reinforced concrete frame and the masonry wall. In the ANSYS program, the normal contact stiffness factor FKN was calibrated in order to obtain the lowest possible penetration between the surfaces without causing numerical inconsistency.

Other parameters defined in the contact problem are the friction coefficient $(\mu)$ among the frame-masonry surfaces, the maximum shear strength (stress) between the surfaces $\left(f_{v \text { max }}\right)$ and the cohesion $\left(\tau_{0}\right)$. These parameters were obtained according to the FEMA 306 [34] recommendations, presented in Table 4. In this Table, $f_{p}$ is the compressive strength of the prism.

Finite Element Analysis does not provide the average stress acting on the entire infill wall, but the stress on nodal points of the infill wall. Thus, in order to avoid acting stresses larger than the strength stresses, the maximum shear stress mobilized between the framemasonry surfaces was limited to $f_{v, \text { max }}=\alpha \cdot f_{v}$, where $\alpha=1,5$. Equation 4 calculates the average shear stress on the infill wall $\left(f_{v}\right)$, as recommended by FEMA 306 [34].

$f_{v}=\frac{\tau_{0}+0,5 \sigma_{\mathrm{g}} \cdot \mu}{1-\mu \cdot \operatorname{tg} \theta}$

$f_{v}$ - average shear stress on the infill wall;

$\mu-$ friction coefficient among the surfaces;

\section{Table 4}

Parameters related to the contact problem

\begin{tabular}{ccc}
\hline Parameter & $\begin{array}{c}\text { ANSYS } \\
\text { Nomenclature }\end{array}$ & Value \\
\hline $\begin{array}{c}\text { Cohesion } \\
\left(\tau_{0}\right)\end{array}$ & COHE & $\tau_{0}=\frac{f_{p}}{40}$ \\
$\begin{array}{c}\text { Maximum shear } \\
\text { stress mobilized } \\
\left(f_{v, \text { max }}\right)\end{array}$ & TAUMAX & $f_{v, \text { max }}=1,5 \cdot f_{v}$ \\
$\begin{array}{c}\text { Friction coefficient } \\
(\mu)\end{array}$ & Friction coefficient & 0.7 \\
\hline
\end{tabular}

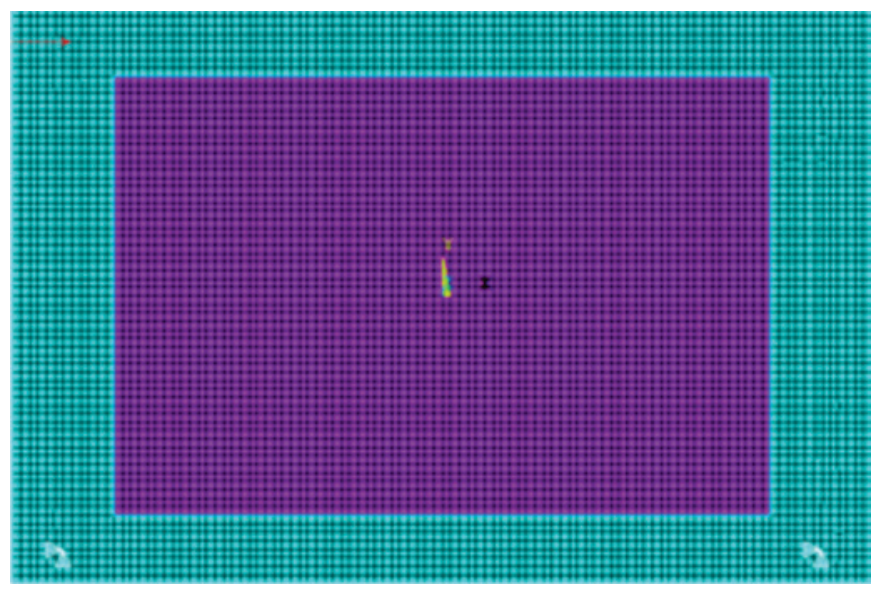

(b)

\section{Figure 4}

FEM model of masonry infilled reinforced concrete frames: a) boundary conditions; b) model discretization 


\section{Table 5}

Minimum values for compressive strength of the clay brick $\left(f_{b}\right)$. Adapted from ABNT NBR 15270-1 [35]

\begin{tabular}{cc}
\hline Direction of the holes & $\begin{array}{c}\mathbf{f}_{b} \\
(\mathbf{M P a})\end{array}$ \\
\hline Horizontal & $\geq 1.5$ \\
Vertical & $\geq 3.0$ \\
\hline
\end{tabular}

Table 6

Material mechanical properties

\begin{tabular}{cccc}
\hline \multirow{2}{*}{ Material } & \multirow{2}{*}{ Concrete } & \multicolumn{2}{c}{ Clay brick } \\
\cline { 3 - 4 } & & $\mathbf{f}_{\mathrm{b}}=\mathbf{1 . 5} \mathbf{M P a}$ & $\mathbf{f}_{\mathrm{b}}=\mathbf{3 . 0} \mathbf{~ M P a}$ \\
\hline $\mathrm{E}(\mathrm{MPa})$ & 25000 & 450 & 900 \\
$v$ & 0.2 & 0.15 & 0.15 \\
\hline
\end{tabular}

$\sigma_{g}-$ vertical stress due to self weight of the infill wall (Equation 5); $\operatorname{tg} \theta$ - height-to-length ratio of the infill wall;

$\tau_{0}$ - cohesion.

$\sigma_{g}=\frac{W_{a l v}}{l \cdot t}$

I - wall length;

$t$ - wall thickness;

$W_{a / v}-$ total wall weight.

\subsection{Mechanical properties}

Both the reinforced concrete frame and the masonry wall were assumed as linear elastic materials (in tension and compression) in order to simplify the analysis. Due to this simplification and the fact that the modeling assumes the homogenization of the materials, neither the mechanical characteristics of the steel reinforcement nor masonry mortars are mentioned. In addition, according to ABNT NBR 15270-1 [35], the clay brick has minimum limits for compressive strength depending on the direction of the holes (horizontal or vertical) with which it is built. These limits are expressed in Table 5. Thus, in the numerical analysis, these minimum limits were chosen to establish the strength of the brick in numerical models.

The mechanical properties adopted for the materials, such as the modulus of elasticity $(E)$ and Poisson's coefficient $(v)$ values, are indicated in Table 6. The reinforced concrete properties were obtained in ABNT NBR 6118 [33] assuming C25 concrete strength class and the masonry properties, according to ABNT NBR 15812 [36]. The elasticity modulus of masonry was obtained as a result of the compressive strength of the prism $\left(\mathrm{f}_{\mathrm{p}}\right)$, according to Equation 6.

$E=600 \cdot f_{p}$

According to Parsekian, Hamid and Drysdale [1], the relationship between the compressive strength of the prism and the compressive strength of the brick can vary between 0.30 and 0.60 (clay bricks). For this paper, an intermediate value, corresponding to $50 \%$ of the brick strength was considered for the strength of the prism.

\subsection{Application of horizontal loads to the models}

Alva et al. [6] procedure was followed in order to choose the hori- zontal loads values to be applied in the models. Initially, horizontal loads were applied concentrated on the frames (beam's longitudinal axis) that produced interstory drifts equal to $H / 850$ in the models without infill walls - limit recommended by ABNT NBR 6118 [33] for the Serviceability Limit States verification, as Equation 7. These forces have been reapplied in the models with infill walls for the internal forces in the masonry analysis, in order to verify their stresses level when two consecutive floors are designed with the limits of interstory drifts of ABNT NBR 6118 [33] regarding to Serviceability Limit States.

$\delta_{h} \leq \frac{H}{850}$

$\delta_{h}-$ interstory drift (consecutive floors);

$H$ - Distance between beams or between consecutive floors (Figure 2).

Once the forces were defined, the walls were inserted in the MDE and FEM models, in order to assess the expressions of the literature intended to calculate the equivalent diagonal width. In addition, it has been checked if the acting stresses in the infill wall do not exceed the stresses strengths. Equation 4, Equation 8 and 9 from FEMA 306 [34] allow, respectively, the computation of shear, diagonal tensile and diagonal compressive strength stresses of the infill wall.

$f_{t, \theta}=\frac{f_{p}}{40}$

$f_{c, \theta}=\frac{f_{p}}{2}$

$f_{c, \theta}$ - diagonal compressive strength of the infill panel;

$f_{t, \theta}^{c, \theta}-$ diagonal tensile strength of the infill panel.

\section{Results analysis}

The equivalent diagonal widths in the MDE models were calibrated with the criterion of displacements, i.e, so that the interstory drift in these models were the same as those obtained in the FEM models. Figures 5 to 10 contain the comparative graphs of the values from the equivalent diagonal strut width according to the

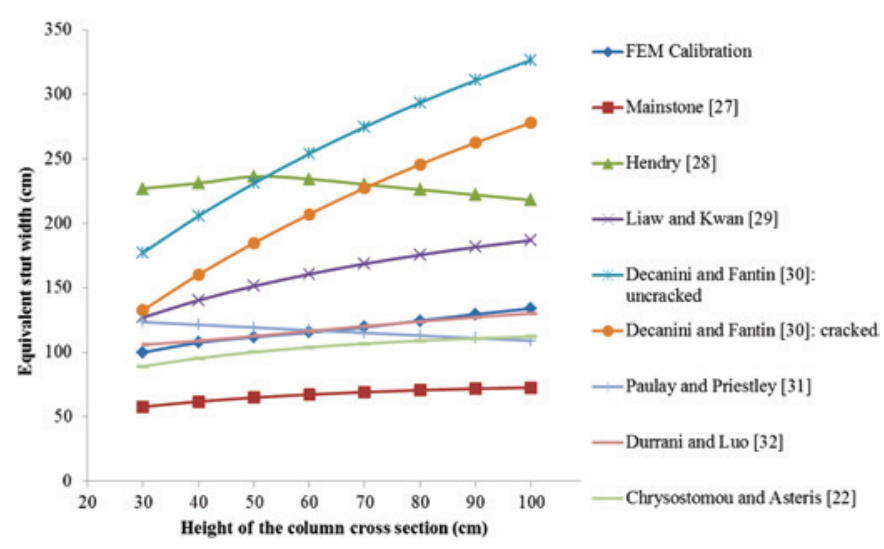

Figure 5

Values of equivalent strut widths vs. height of the column cross section: B15V40 models 
expressions from the bibliography addressed in this paper and according to the results obtained by FEM calibration.

By analyzing the graphs of Figures 5 to 10 , it is possible to note the increase of the width of the equivalent diagonal strut as the height of the column is increased. All expressions analyzed can simulate this tendency of increase, except for Paulay and Priestley [31].

The increase of the compressive strength of the clay brick (from 1.5 $\mathrm{MPa}$ to $3.0 \mathrm{MPa}$ ) led to a reduction of the equivalent strut width (was

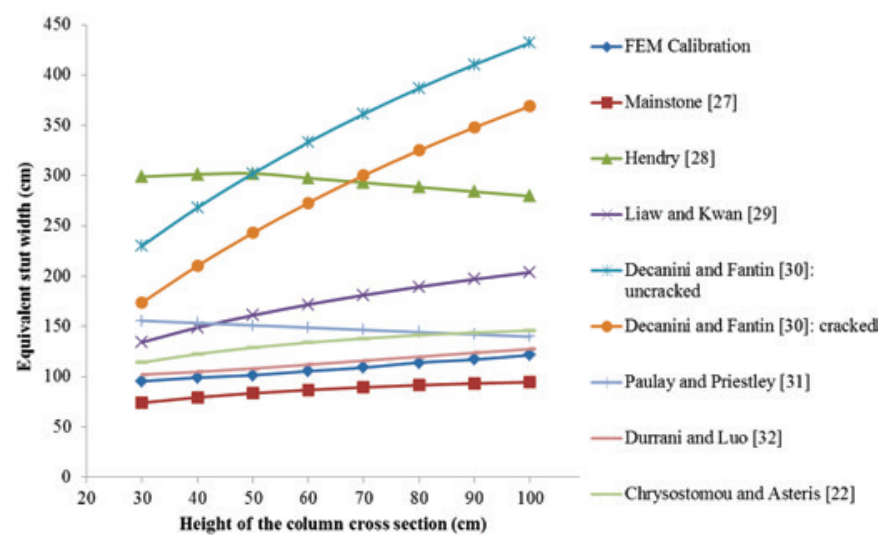

Figure 6

Values of equivalent strut widths vs. height of the column cross section: B15V50 models

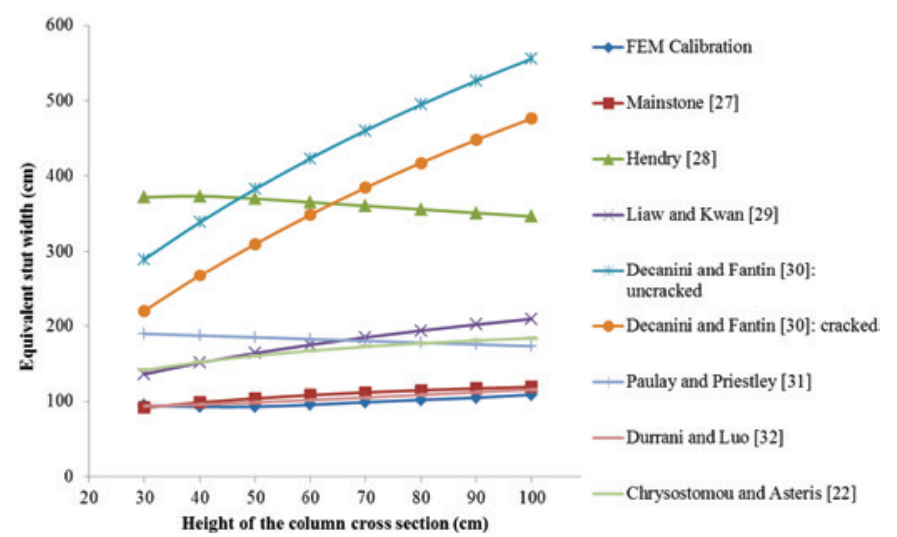

Figure 7

Values of equivalent strut widths vs. height of the column cross section: B15V60 models

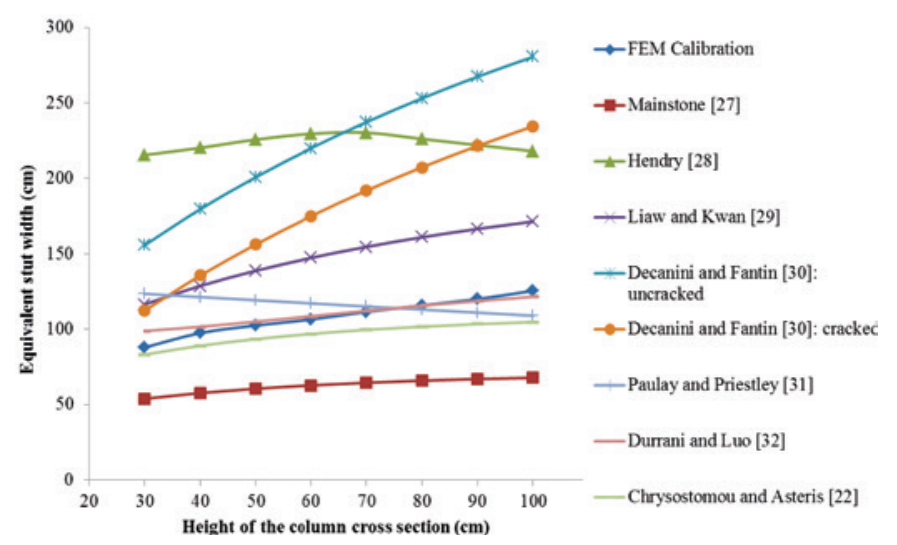

Figure 8

Values of equivalent strut widths vs. height of the column cross section: B30V40 models about $8 \%$ ) referring to the results obtained by FEM calibration. Using the analytical expressions discussed in this paper, such reductions assumed the following values: about $7 \%$ for the Mainstone [27], Durrani and Luo [32] and Chrysostomou and Asteris [22] expressions; about $8 \%$ for the Liauw and Kwan [29] expression; about 16\% for Hendry [28] and Decanini and Fantin [30] expressions.

It is possible to note that the expression proposed by Durrani and Luo [32] led to results closer to the FEM calibration results. Moreover, this expression was the only one that could simulate the decrease of the equivalent strut width value based on the height increase of the beam section (for a same block resistance), a performance also observed in the calibration results via FEM. It is important to note that the good proximity to FEM results may have ocurred because this expression is the only expression among those addressed in this paper which considers the beam mechanical properties.

By analyzing the extreme values provided by the expressions in Figures 5 to 10, it can be seen that Mainstone [27] expression was the most conservative, confirming what is stated in the international bibliography: this expression, in fact, provides the lowest values of equivalent strut width in relation to the others. In turn, the expressions proposed by Decanini and Fantin [30] (uncraked wall) and by Hendry [28] were the ones which provided the highest values. As it can be seen in the graphs from Figures 5 to 10 , the expressions present significant differences among them for value of the equivalent strut width. However, for structural design purposes, the differences that matter are related to the internal forces. In addition,

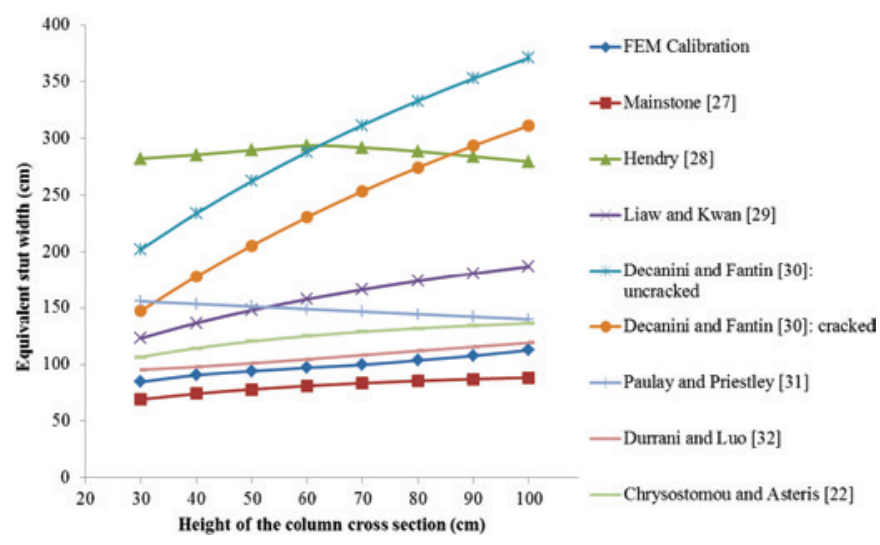

Figure 9

Values of equivalent strut widths vs. height of the column cross section: B30V50 models

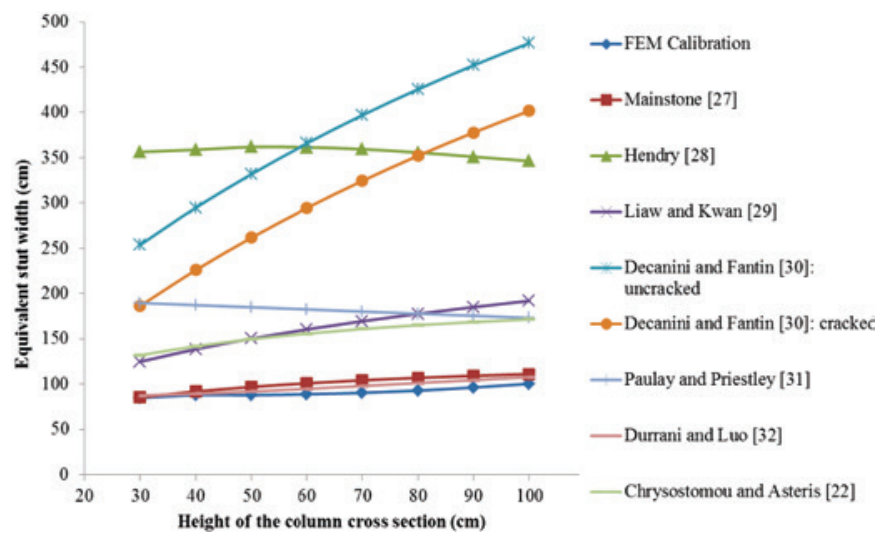

Figure 10

Values of equivalent strut widths vs. height of the column cross section: B30V60 models 
because the infilled frame consists of two materials with different mechanical properties, the percentage differences in the equivalent strut width are not expected to be the same as in the internal forces, either in axial force in diagonal strut, which simulates the wall, or in the beams and columns internal forces. Tables 7 to 10 contain results of axial force in equivalent diagonal strut and bending moments at the ends of the upper beam for the B15V40P100, B30V40P100, B15V60P30 and B30V60P30 models. The results presented in these tables allow to analyze the variation occurred in the internal forces based on different values provided by the literature expressions and cited in this paper to obtain the equivalent strut width. In the mentioned Tables, the FEM calibration column refers to the results obtained with the bar frame models whose equivalent strut width (pinned strut representing the wall) was calibrated with the FEM model results. The calibration criterion was the interstory drift equality.

\section{Table 7}

Comparison of values obtained from B15V40P100 model $\left(I_{v} / I_{p}=0.064\right)$

\begin{tabular}{cccccc}
\hline Equation & FEM Calibration & Mainstone [27] & $\begin{array}{c}\text { Liaw and Kwan } \\
\text { [29] }\end{array}$ & $\begin{array}{c}\text { Decanini and } \\
\text { Fantin [30]: } \\
\text { uncracked }\end{array}$ & $\begin{array}{c}\text { Durrani and Luo } \\
\text { [32] }\end{array}$ \\
\hline $\begin{array}{c}\text { Equivalent strut } \\
\text { width (cm) }\end{array}$ & 134.0 & 72.7 & 186.8 & 326.6 & 130.2 \\
$\begin{array}{c}\text { Axial force in } \\
\text { equivalent diagonal } \\
\text { strut (kN) }\end{array}$ & 38.1 & 25.6 & 45.7 & 58.2 & 37.5 \\
$\begin{array}{c}\text { Bending moment } \\
\text { at the beam end } \\
\text { (kN.m) }\end{array}$ & 33.6 & 41.5 & 28.9 & 21.0 & 34.0 \\
\hline
\end{tabular}

\section{Table 8}

Comparison of values obtained from B30V40P100 model $\left(I_{v} / I_{p}=0.064\right)$

\begin{tabular}{|c|c|c|c|c|c|}
\hline Equation & FEM Calibration & Mainstone [27] & $\begin{array}{c}\text { Liaw and Kwan } \\
\text { [29] }\end{array}$ & $\begin{array}{l}\text { Decanini and } \\
\text { Fantin [30]: } \\
\text { uncracked }\end{array}$ & $\begin{array}{c}\text { Durrani and Luo } \\
\text { [32] }\end{array}$ \\
\hline $\begin{array}{l}\text { Equivalent strut } \\
\text { width }(\mathrm{cm})\end{array}$ & 125.5 & 67.9 & 171.3 & 280.5 & 121.5 \\
\hline $\begin{array}{l}\text { Axial force in } \\
\text { equivalent diagonal } \\
\text { strut }(\mathrm{kN})\end{array}$ & 52.4 & 38.4 & 59.2 & 68.7 & 51.7 \\
\hline $\begin{array}{c}\text { Bending moment } \\
\text { at the beam end } \\
(\mathrm{kN} . \mathrm{m})\end{array}$ & 24.7 & 33.4 & 20.4 & 14.5 & 25.1 \\
\hline
\end{tabular}

\section{Table 9}

Comparison of values obtained from B15V60P30 model $\left(I_{v} / I_{p}=8\right)$

\begin{tabular}{cccccc}
\hline Equation & FEM Calibration & Mainstone [27] & $\begin{array}{c}\text { Liaw and Kwan } \\
\text { [29] }\end{array}$ & $\begin{array}{c}\text { Decanini and } \\
\text { Fantin [30]: } \\
\text { uncracked }\end{array}$ & $\begin{array}{c}\text { Durrani and Luo } \\
\text { [32] }\end{array}$ \\
\hline $\begin{array}{c}\text { Equivalent strut } \\
\text { width (cm) } \\
\begin{array}{c}\text { Axial force in } \\
\text { equivalent }\end{array}\end{array}$ & 94.5 & 91.7 & 136.2 & 371.9 & 93.8 \\
$\begin{array}{c}\text { diagonal strut (kN) } \\
\text { Bending moment } \\
\text { at the beam end } \\
\text { (kN.m) }\end{array}$ & 17.7 & 17.4 & 21.0 & 28.7 & 17.6 \\
\hline
\end{tabular}

\section{Table 10}

Comparison of values obtained from B30V60P30 model $\left(I_{v} / I_{p}=8\right)$

\begin{tabular}{cccccc}
\hline Equation & FEM Calibration & Mainstone [27] & $\begin{array}{c}\text { Liaw and Kwan } \\
\text { [29] }\end{array}$ & $\begin{array}{c}\text { Decanini and } \\
\text { Fantin [30]: } \\
\text { uncracked }\end{array}$ & $\begin{array}{c}\text { Durrani and Luo } \\
\text { [32] }\end{array}$ \\
\hline $\begin{array}{c}\text { Equivalent strut } \\
\text { width (cm) } \\
\begin{array}{c}\text { Axial force in } \\
\text { equivalent }\end{array}\end{array}$ & 85.0 & 85.6 & 129.4 & 356.4 & \\
$\begin{array}{c}\text { diagonal strut (kN) } \\
\text { Bending moment } \\
\text { at the beam end } \\
\text { (kN.m) }\end{array}$ & 22.9 & 23 & 26.2 & 31.9 & 23.2 \\
\hline
\end{tabular}


According to the results of Tables 7 to 10 , the percentage differences among the equivalent strut width values, axial forces on the equivalent diagonal strut and bending moments at the ends of the beams for the B15V40P100, B30V40P100, B15V60P30 and B30V60P30 were calculated. Such differences, indicated by the graphs from Figures 11 to 14 were calculated taking into account FEM calibration results, which are considered as a reference (accuracy basis).

The results of Figures 11 to 14 indicate that the percentage accuracy loss in the evaluation of the equivalent strut width is not

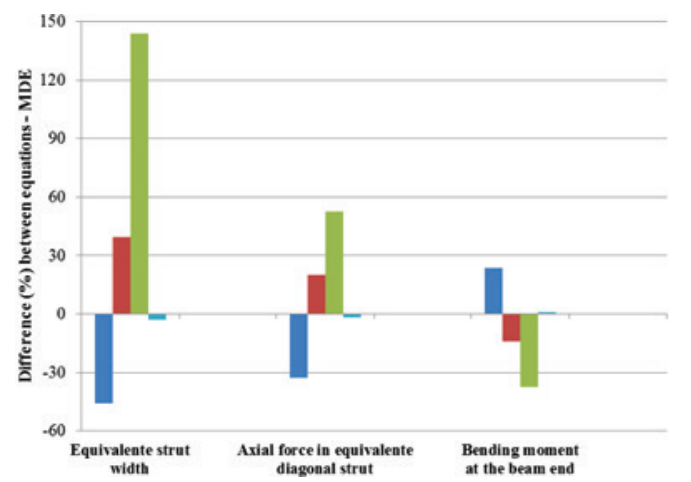

- Mainstone [27]

- Liaw and Kwan [29]

$=$ Decanini and Fantin [30]: uncracked

$=$ Durrani and Luo [32]

\section{Figure 11}

Percentage differences for model B15V4OP100

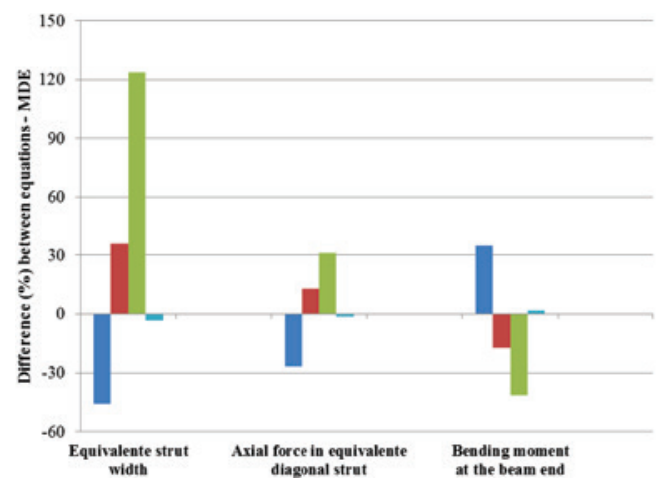

- Mainstone [27]

- Liaw and Kwan [29]

$=$ Decanini and Fantin [30]: uncracked

$=$ Durrani and Luo [32]

\section{Figure 12}

Percentage differences for model B30V40P100

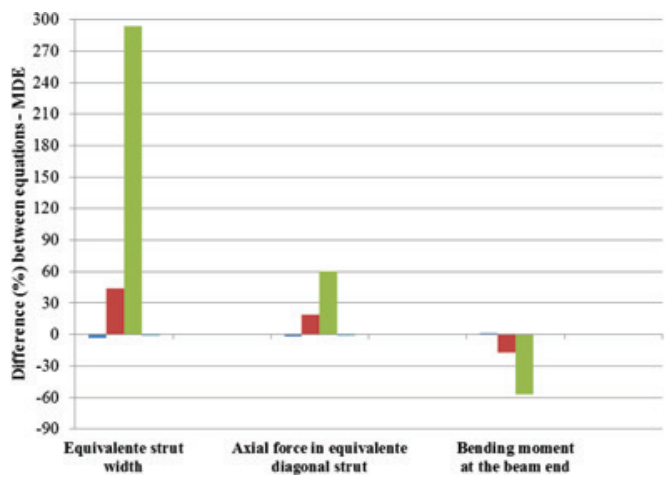

- Mainstone [27]

= Liaw and Kwan [29]

= Hendry [28]

$=$ Durrani and Luo [32]

\section{Figure 13}

Percentage differences for model B15V60P30 equally reflected in the percentage accuracy loss related to the internal forces. To exemplify, the results obtained can be analyzed by using the expression of Liaw and Kwan [29] in Figures 11 to 14: although this expression leads to differences of accuracy $40 \%$ in the equivalent strut width, the differences in terms of internal forces

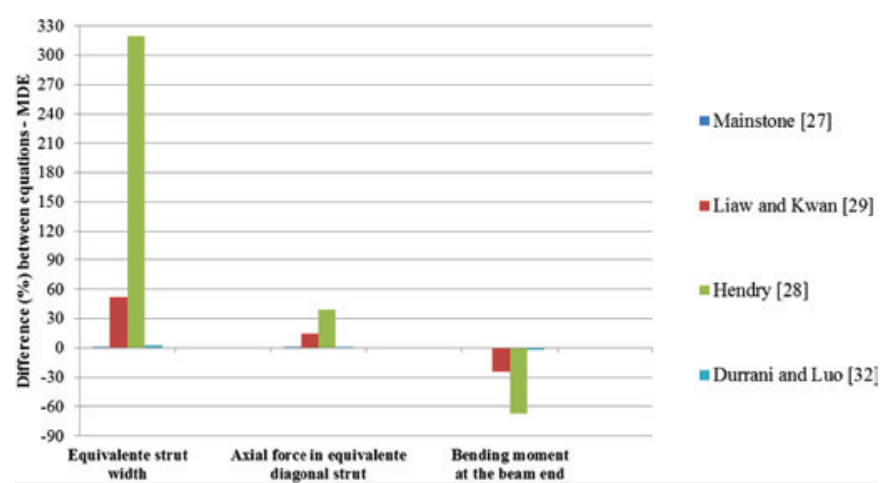

Figure 14

Percentage differences for model B30V60P30

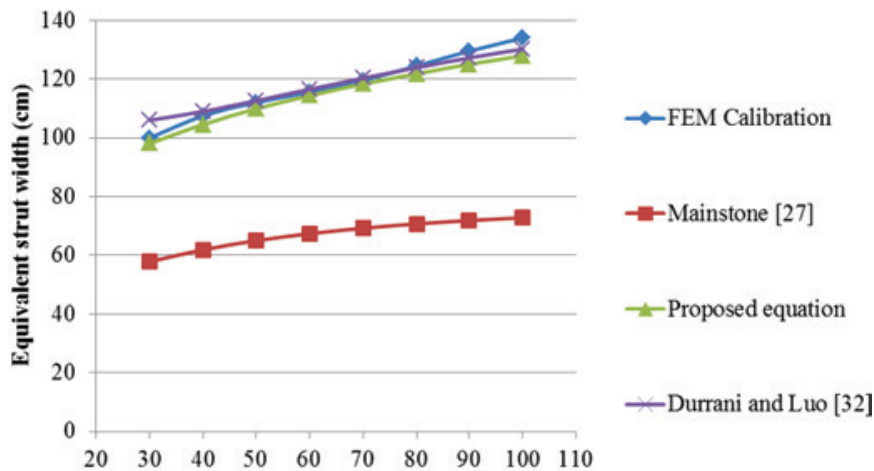

Figure 15

Comparison between equations: Mainstone [27], Durrani and Luo [32] and proposed equation for B15V40 models

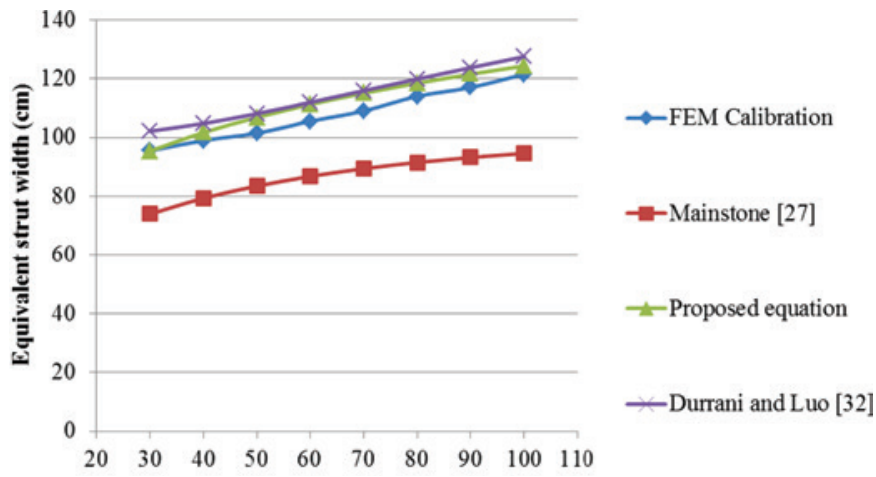

Figure 16

Comparison between equations: Mainstone [27], Durrani and Luo [32] and proposed equation for B15V50 models 


\subsection{Proposta de expressão para obtenção da largura da diagonal equivalente}

Although it is one of the expressions most known by researchers and recommended in some standard codes, Mainstone's [27] expression did not lead to satisfactory results, as numerical simulations showed using FEM. Thus, a correction was made in Mainstone [27] expression aiming a new expression applicable to buildings with characteristics similar to the models analyzed in this paper is proposed. Similar characteristics refer to the theoretical spans of the beams $(4.50 \mathrm{~m}, 6.00 \mathrm{~m}$ and $7.50 \mathrm{~m})$, the interstory height $(3.0 \mathrm{~m})$ and the masonry strength (blocks with compressive strength of $1.5 \mathrm{MPa}$ and $3.0 \mathrm{MPa}$ ). From the results of the numerical analyzes and by varying (by tries) the parameters from the Mainstone expression [27], the proposed expression was obtained, according to Equation 10.

$\mathrm{a}=0,51 \cdot\left(\lambda_{\mathrm{H}}\right)^{-0,3} \cdot \operatorname{sen} \theta . \mathrm{D}$

In Figures 15 to 20 it is possible to notice that the proposed expression presented closer results to the numerical calibration via FEM if compared to the original Mainstone expression [27].

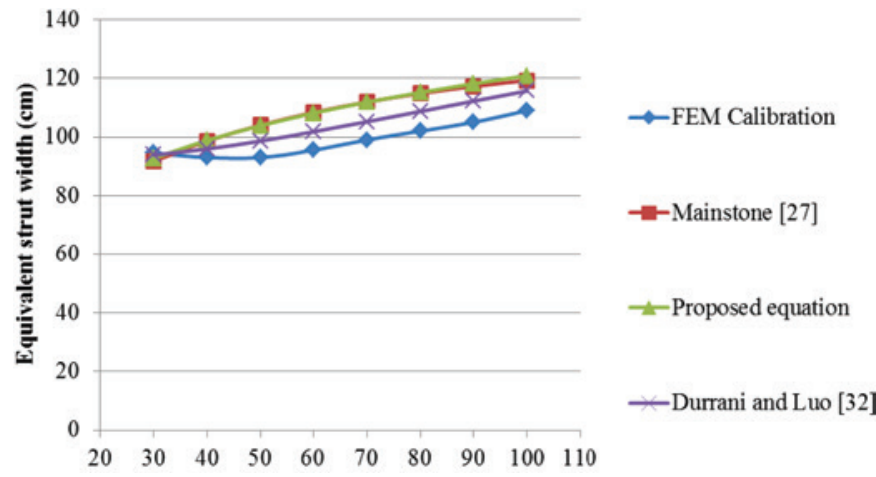

Figure 17

Comparison between equations: Mainstone [27], Durrani and Luo [32] and proposed equation for B15V60 models

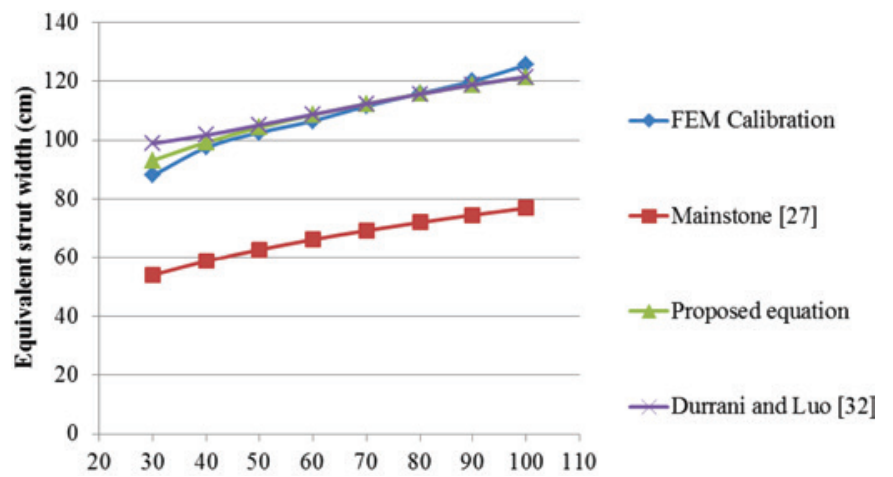

Figure 18

Comparison between equations: Mainstone [27], Durrani and Luo [32] and proposed equation for B30V40 models

\subsection{Acting stresses vs. strength stresses on the infill wall}

The acting stresses in the infill masonry wall were obtained in the FEM modeling. Compressive principal stresses, tensile principal stresses and shear stresses were object of analysis. The distribution of such stresses in the panel is shown in Figure 21 for one of the analyzed models. Figure 21 also shows the deformed shape of the infilled frame and the separation between the frame and the wall. The acting stresses values were compared to the values of the strength stresses calculated according to FEMA 306 [34], as presented in Equations 4, 8 and 9.

Tables 11 and 12 show the acting stresses values (tensile principal stresses, compressive principal stresses and shear stresses) besides the strength stresses of the models, in order to evaluate the predicted cracking type.

In all 48 analyzed models, there was no diagonal compression failure. For models with blocks of $1.5 \mathrm{MPa}$ compressive strength, the ratio between the compressive principal stresses and the diagonal compressive strength was between 0.42 and 0.77 , with an average value of 0.67 . For models with $3.0 \mathrm{MPa}$ compressive strength

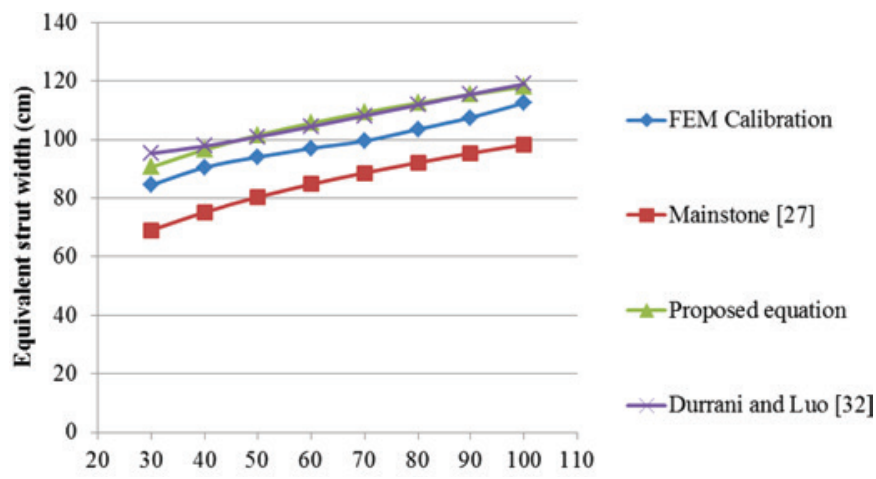

Figure 19

Comparison between equations: Mainstone [27], Durrani and Luo [32] and proposed equation for B30V50 models

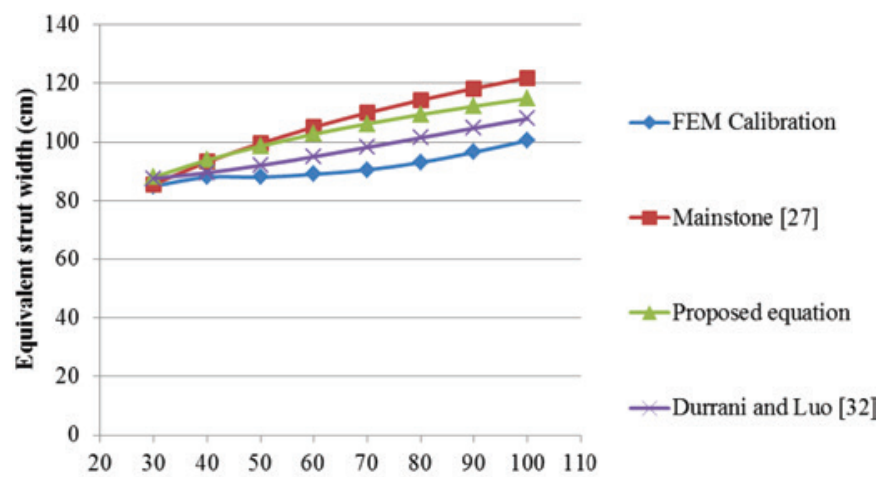

Figure 20

Comparison between equations: Mainstone [27], Durrani and Luo [32] and proposed equation for B30V60 models 

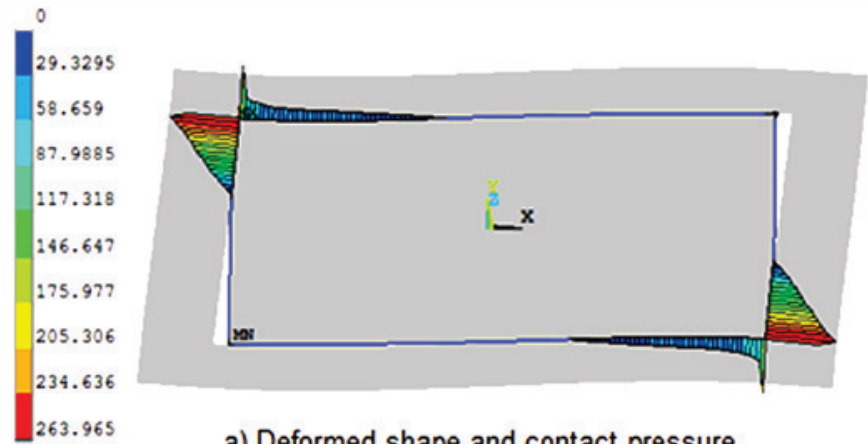

a) Deformed shape and contact pressure

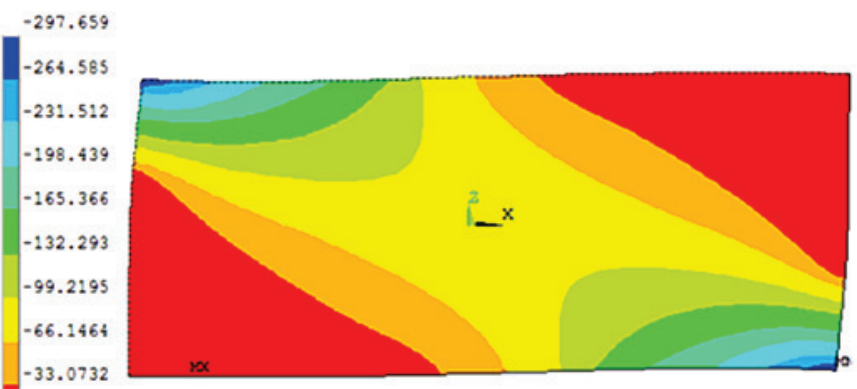

c) Compressive principal Stress
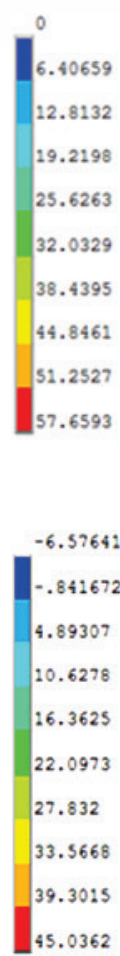

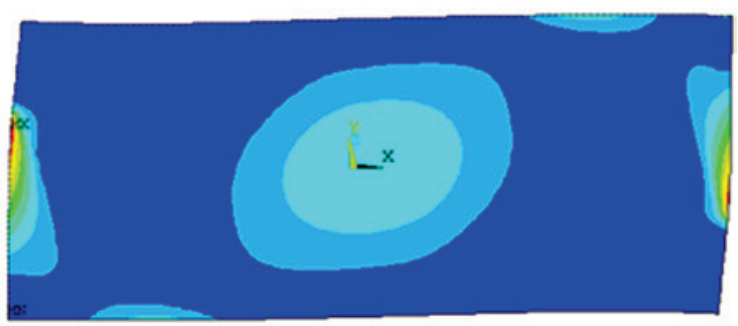

b) Tensile principal stress

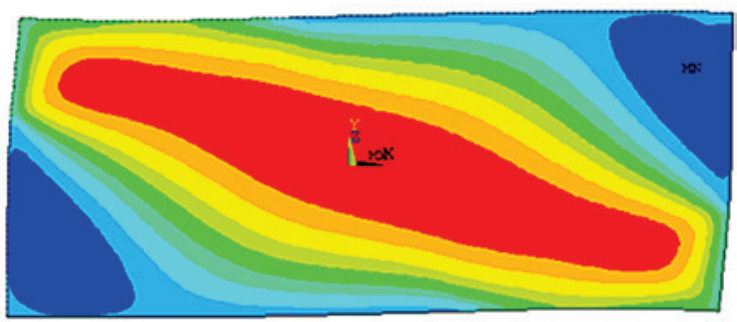

d) Shear Stress

Figure 21

Contact between frame-infill wall and distribution of stresses in the B15V50P50 model (units in $\mathrm{kN} / \mathrm{m}^{2}$ )

\section{Table 11}

Acting and strength stresses in infill walls for B15 models. Units in $\mathrm{kN} / \mathrm{m}^{2}$

\begin{tabular}{|c|c|c|c|c|c|}
\hline \multicolumn{6}{|c|}{$f_{b}=1.5 \mathrm{MPa}(B 15) \rightarrow f_{c, \theta}=375 \mathrm{kN} / \mathrm{m}^{2} \quad f_{t, \theta}=18,75 \mathrm{kN} / \mathrm{m}^{2}$} \\
\hline Model & Compressive & Tensile & Shear & $f_{v}$ & Predicted cracking \\
\hline B15V40P30 & 158 & 12.3 & 32.4 & 52.6 & None \\
\hline B15V40P40 & 205 & 16.9 & 42.6 & 53.6 & None \\
\hline B15V40P50 & 233 & 19.3 & 50.0 & 54.7 & Tensile \\
\hline B15V40P60 & 252 & 21.1 & 55.4 & 55.9 & Tensile \\
\hline B15V40P70 & 264 & 22.7 & 59.8 & 57.3 & Tensile/Shear \\
\hline B15V40P80 & 279 & 24.5 & 63.9 & 58.7 & Tensile/Shear \\
\hline B15V40P90 & 292 & 26.4 & 68.0 & 60.3 & Tensile/Shear \\
\hline B15V40P100 & 306 & 28.1 & 72.2 & 62.1 & Tensile/Shear \\
\hline B15V50P30 & 173 & 7.5 & 26.7 & 43.0 & None \\
\hline B15V50P40 & 217 & 10.4 & 36.0 & 43.3 & None \\
\hline B15V50P50 & 237 & 18.0 & 39.2 & 43.7 & None \\
\hline B15V50P60 & 254 & 18.9 & 42.4 & 44.0 & Tensile \\
\hline B15V50P70 & 265 & 19.2 & 45.0 & 44.4 & Tensile/Shear \\
\hline B15V50P80 & 280 & 19.5 & 47.8 & 44.9 & Tensile/Shear \\
\hline B15V50P90 & 285 & 19.6 & 50.2 & 45.3 & Tensile/Shear \\
\hline B15V50P100 & 295 & 19.8 & 52.8 & 45.8 & Tensile/Shear \\
\hline B15V60P30 & 191 & 4.5 & 20.4 & 38.7 & None \\
\hline B15V60P40 & 227 & 6.4 & 25.7 & 38.9 & None \\
\hline B15V60P50 & 244 & 7.4 & 30.4 & 39.1 & None \\
\hline B15V60P60 & 260 & 8.0 & 36.7 & 39.3 & None \\
\hline B15V60P70 & 267 & 8.3 & 37.2 & 39.4 & None \\
\hline B15V60P80 & 274 & 8.6 & 38.0 & 39.6 & None \\
\hline B15V60P90 & 280 & 8.8 & 38.7 & 39.8 & None \\
\hline B15V60P100 & 288 & 8.9 & 39.6 & 40.1 & None \\
\hline
\end{tabular}


Table 12

Acting and strength stresses in infill walls for B30 models. Units in $\mathrm{kN} / \mathrm{m}^{2}$

\begin{tabular}{|c|c|c|c|c|c|}
\hline \multicolumn{6}{|c|}{$\mathrm{f}_{\mathrm{b}}=3,0 \mathrm{MPa}(\mathrm{B} 30) \rightarrow \mathrm{f}_{\mathrm{c}, \theta}=750 \mathrm{kN} / \mathrm{m}^{2} \quad \mathrm{f}_{\mathrm{t}, \theta}=37,5 \mathrm{kN} / \mathrm{m}^{2}$} \\
\hline Model & Compressive & Tensile & Shear & $f_{v}$ & Predicted cracking \\
\hline B30V40P30 & 216 & 15.4 & 40.9 & 102.3 & None \\
\hline B30V40P40 & 300 & 22.1 & 56.0 & 104.2 & None \\
\hline B30V40P50 & 347 & 25.7 & 67.8 & 106.3 & None \\
\hline B30V40P60 & 374 & 28.1 & 76.5 & 108.7 & None \\
\hline B30V40P70 & 395 & 30.5 & 83.4 & 111.2 & None \\
\hline B30V40P80 & 406 & 33.1 & 89.2 & 114.1 & None \\
\hline B30V40P90 & 416 & 35.2 & 94.9 & 117.2 & None \\
\hline B30V40P100 & 447 & 38.1 & 101.9 & 120.7 & Tensile \\
\hline B30V50P30 & 243 & 11.0 & 35.0 & 83.5 & None \\
\hline B30V50P40 & 330 & 15.7 & 44.7 & 84.2 & None \\
\hline B30V50P50 & 377 & 17.8 & 57.4 & 84.9 & None \\
\hline B30V50P60 & 414 & 18.7 & 63.4 & 85.6 & None \\
\hline B30V50P70 & 427 & 27.8 & 67.2 & 86.4 & None \\
\hline B30V50P80 & 444 & 27.0 & 71.2 & 87.3 & None \\
\hline B30V50P90 & 458 & 26.5 & 75.1 & 88.1 & None \\
\hline B30V50P100 & 480 & 30.1 & 79.7 & 89.1 & None \\
\hline B30V60P30 & 276 & 10.6 & 27.2 & 75.4 & None \\
\hline B30V60P40 & 369 & 15.9 & 39.4 & 75.7 & None \\
\hline B30V60P50 & 429 & 17.9 & 50.8 & 76.1 & None \\
\hline B30V60P60 & 459 & 19.5 & 53.0 & 76.4 & None \\
\hline B30V60P70 & 462 & 20.2 & 53.0 & 76.8 & None \\
\hline B30V60P80 & 476 & 20.9 & 54.3 & 77.2 & None \\
\hline B30V60P90 & 488 & 21.5 & 55.8 & 77.6 & None \\
\hline B30V60P100 & 500 & 21.8 & 57.6 & 78.0 & None \\
\hline
\end{tabular}

blocks, the ratio between the compressive principal stresses and the diagonal compressive strength was between 0.29 and 0.67 , with an average value of 0.53 . It is important to highlight that the non-occurrence of the diagonal compression failure makes valid the results obtained in this paper, since ultimate strength capacity generally occurs due to this type of failure [1, 17, 34].

The occurrence of cracking was predicted in 12 models. For models with bricks of $3.0 \mathrm{MPa}$ compressive strength, the ratio between the main stress strength and the diagonal tensile strength was between 0.28 and 1.02 , with an average value of 0.67 . There was only 1 model with predicted cracking, which is associated with tensile strength stresses. For models with blocks of 1,5 MPa compressive strength, there were 11 models with predicted cracking. The relationship between the tensile principal stresses and the diagonal tensile strength was between 0.24 and 1.50 , with an average value of 0.81 . The relationship between the acting shear stresses and the shear strength stresses was between 0.62 and 1.16 , with an average value of 0.92 . Among the 11 mentioned models, in 8 of these the cracking starts by tensile strength stresses and in the remaining 3 models the cracking starts by shear. It is important to note that the occurrence of tensile strength stresses cracking is not a failure mode of the masonry infill wall, but it is related to a State Service Limit [15].

\section{Final considerations and conclusions}

This paper was focused on the modeling masonry infilled reinforced concrete frames, using equivalent strut model and two-dimensional finite elements for state stress plane with the sliding simulation and separation between reinforced concrete frame and infill masonry wall. Using Finite Element software (ANSYS), 48 models of infilled frames were simulated numerically, with distance between columns and interstory height usual in reinforced concrete buildings. The mechanical properties of the infilled masonry were estimated from the standard minimum strength for clay bricks. The columns dimensions, the beams dimensions (height of the cross section and span) and the masonry compressive strength were varied.

In all models, horizontal loads were applied that induced the frame without masonry to an interstory drift equal to $\mathrm{H} / 850$ (where $\mathrm{H}$ is the distance between consecutive floors), which consists of the maximum interstory drift recommended by NBR 6118 for Serviceability Limit State (conventional modeling, without contribution of the infill walls as resistant elements). The forces were reapplied to the respective frames, but with the presence of masonry in the structural model. From these considerations, the following conclusions were obtained:

With the interstory drift fixed at $\mathrm{H} / 850$, the equivalent strut width increases with the increase of the frame stiffness (dimensions of cross section of the columns). This increase was observed for all the expressions discussed in this paper, except for the expression of Paulay and Priestley [31]. It was also noticed that the increase of the frame stiffness produced acting stresses increases in the infill walls;

- The relevant differences between the equivalent strut width values provided by the main expressions from the literature were confirmed. On the other hand, Durrani and Luo [32] ex- 
pression provided the closest results comparing to the results obtained with FEM models. It is worth noting that this expression is the only one that considers the mechanical properties of the beam in the equivalent strut width calculation;

- Internal forces obtained in the infilled frame were compared to the values of the equivalent diagonal strut width calculated with the different expressions. It was noted that the internal forces in the infilled frame vary less than the equivalent strut width variation;

- A new expression was proposed for the equivalent strut width by a modification in the Mainstone expression [27], thus obtaining good results in comparison to the FEM models. It is recommended, however, that the proposed new expression be used for buildings with geometrical characteristics and mechanical properties similar to the infilled frame models analyzed in this paper. For beams, columns and masonry walls with higher strength than those analyzed (such as concrete blocks), the authors suggest possible changes in Mainstone expression [27] as a theme for future studies [27] to improve the accuracy of the results;

- The analysis of 48 FEM models indicated the important influence of the masonry compressive strength for verification of the Serviceability Limit State related to excessive lateral deformations. Based on the comparison of the acting stresses with the strength stresses, in only 1 model was predicted the cracking of the masonry wall with bricks of $3.0 \mathrm{MPa}$. For masonry walls with $1.5 \mathrm{MPa}$ bricks of compressive strength, cracking was predicted in 11 models. These results also indicate that the limitation of NBR 6118 for interstory drift $(\mathrm{H} / 850)$ does not guarantee the absence of cracking of the infill walls due to the lateral deformability of the principal structure, which must be accompanied by a minimum strength of masonry.

\section{Acknowledgements}

To CAPES for financial support.

\section{References}

[1] PARSEKIAN, G. A.; HAMID, A. A.; DRYSDALE, R. G. Comportamento e dimensionamento de alvenaria estrutural. $2^{\mathrm{a}}$ ed. São Carlos: EdUFSCar, 2013. 723 p.

[2] ASTERIS, P.G.; ANTONIOU, S.T.; SOPHIANOPOULOS, D.S.; CHRYSOSTOMOU, C.Z. Mathematical Macromodeling of Infilled Frames: State of the Art. Journal of the Structural Engineering, v.137, n.12, p.1508-1517, 2011.

[3] MORANDI, P.; HAK, S.; MAGENES, G. Performancebased interpretation of in-plane cyclic tests on RC frames with strong masonry infills. Engineering Structures, v.156, p.503-521, 2018.

[4] ARAÚJO, J. M. Projeto estrutural de edifícios de concreto armado. $3^{\mathrm{a}} \mathrm{ed}$. Rio Grande: Editora DUNAS, 2014. 306p.

[5] DOUDOUMIS, I.N. Finite element modelling and investigation of the behaviour of elastic infilled frame under monotonic loading. Engineering Structures, v.29, p.1004-1024, 2007.

[6] ALVA, G. M. S.; KAMINSKI JR., J.; MOHAMAD, G.; SILVA, L. R. Estado limite de serviço de deformações horizontais excessivas com a consideração das alvenarias de preenchi- mento no modelo estrutural. Revista IBRACON de Estruturas e Materiais, v.8, n. 3, p.390-426, 2015.

[7] ASTERIS, P.G.; CAVALERI, L.; DI TRAPANI, F.; SARTHOSIS, V. A macro-modeling approach for the analysis of infilled frame structures considering the effects of openings and vertical loads. Structure and Infrastructure Engineering, v.12, n.5, p.551-566, 2016.

[8] ALVARENGA, R. C. S. S. Análise teórico-experimental de estruturas compostas de pórticos de aço preenchidos com alvenaria de concreto celular autoclavado. $331 \mathrm{p}$. Tese (Doutorado) - Universidade de São Paulo, São Carlos, 2002.

[9] SANTOS, E.M. Influência da alvenaria no comportamento estrutural de edifícios altos de concreto armado. 132p. Dissertação (Mestrado) - Universidade Católica de Pernambuco, Recife, 2007.

[10] TANAKA, E.S. Influência da alvenaria dotada de aberturas na rigidez global de um edifício. 90p. Dissertação (Mestrado) - Universidade Estadual de Campinas, Campinas, 2011.

[11] MADIA, F.C. Estudo de pórticos preenchidos com alvenaria. 142p. Dissertação (Mestrado) - Universidade Federal de São Carlos, São Carlos, 2012.

[12] SILVA, L. R. Modelagem de pórticos de concreto armado preenchidos com a consideração de aberturas nos painéis de alvenaria. 139p. Dissertação (Mestrado em Engenharia Civil) - Universidade Federal de Santa Maria, Santa Maria, 2014.

[13] SOUSA, P.V.A. Efeito dos painéis de vedação nas características dinâmicas de edificações de concreto armado. 106p. Dissertação (Mestrado em Engenharia Civil) - Universidade Federal do Rio de Janeiro, Rio de Janeiro, 2014.

[14] POLYAKOV, S. V. Masonry in framed buildings (Godsudarstvenoe Isdatel'stvo Literatury Po Stroidal stvui Architecture. Moscow, 1956). Traduzido por G. L. Cairns, 1963. National Lending Library for Science and Technology, Boston.

[15] SANEINEJAD, A.; HOBBS, B. Inelastic design of infilled frames. Journal of Structural Engineering, v.121, n.4, p.634-650, 1995.

[16] MADAN, A.; REINHORN, A.M.; MANDER, J.B.; VALLES, R.E. Modeling of masonry infill panels for structural analysis. Journal of Structural Engineering, v.123, n.10, p.1295-1302, 1997.

[17] FLANAGAN, R.D.; BENNETT, R.M. In-Plane Behavior of Structural Clay Tile Infilled Frames. Journal of Structural Engineering, v.125, n.6, p.590-599, 1999.

[18] EL-DAKHAKHNI, W.W.; ELGAALY, M.; HAMID, A.A. ThreeStrut Model for Concrete Mansory-Infilled Steel Frames. Journal of the Structural Engineering, v.129, n.2, p.177-185, 2003.

[19] CRISAFULLI, F.J.; CARR, A.J. Proposed Macro-Model for the Analysis of Infilled Frame Structures. Bulletin of the New Zealand Society for Earthquake Engineering, v.40, n.2, p.69-77, 2007.

[20] DOLSEK, M.; FAJFAR, P. The effect of masonry infills on the seismic response of a four-storey reinforced concrete frame - a deterministic assessment. Engineering Structures, v.30, p.1991-2001, 2008.

[21] TASNIMI, A.A.; MOHEBKHAH, A. Investigation on the behavior of brick-infilled steel frames with openings, experimental and analytical approaches. Engineering Structures, v.33, p.968-980, 2011. 
[22] CHRYSOSTOMOU, C.Z.; ASTERIS, P.G. On the in-plane properties and capacities of infilled frames. Engineering Structures, v.41, p.385-402, 2012.

[23] ASTERIS, P.G.; GIANNOPOULOS, I.P.;CHRYSOSTOMOU, C.Z. Modeling of Infilled Frames with Openings. The Open Construction and Building Technology Journal, v.6, p.81-91, 2012.

[24] UVA, G.; RAFFAELE, D.; PORCO, F.; FIORE, A. On the role of equivalent strut models in the seismic assessment of infilled RC buildings. Engineering Structures, v.42, p.83-94, 2012.

[25] MARTINELLI, E.; LIMA, C.; DE STEFANO, G. A simplified procedure for Nonlinear Static analysis of masonry infilled RC frames. Engineering Structures, v.101, p.591-608, 2015.

[26] OZTURKOGLU, O.; UCAR, T.; YESILCE, Y. Effect of masonry infill walls with openings on nonlinear response of reinforced concrete frames. Earthquakes and Structures, v.12, n.3, p.333-347, 2017.

[27] MAINSTONE, R. J. Supplementary note on the stiffness and strengths of infilled frames. Building Research Station, Garston, UK, 1974.

[28] HENDRY, A. Structural Brickwork. MacMillan, London, 1981.

[29] LIAW, T. C.; KWAN, K. H. Nonlinear behavior of non-integral infilled frames. Computers and Structures, v.18, n.3, p.551-560, 1984.

[30] DECANINI, L. D.; FANTIN, G. E. Modelos simplificados de la mampostería incluida en porticos. Caracteristicas de stiffnessy resistencia lateral en estado limite. Jornadas Argentinas de Ingeniería Estructural, v.2, Buenos Aires, Argentina, p.817-836, 1987.

[31] PAULAY, T.; PRIESTLEY, M. J. N. Seismic design of reinforced concrete and masonry buildings. Wiley, New York, 1992. $768 \mathrm{p}$

[32] DURRANI, A.J.; LUO, Y.H. Seismic retrofit of flat-slab buildings with masonry infills. Proceedings from the NCEER Workshop on Seismic Response of Masonry Infills, National Center for Engineering Earthquake, Buffalo, N.Y., 1994.

[33] ASSOCIAÇÃO BRASILEIRA DE NORMAS TÉCNICAS. NBR 6118:2014: Projeto de estruturas de concreto - Procedimento. Rio de Janeiro, ABNT, 2014.

[34] FEDERAL EMERGENCY MANAGEMENT AGENCY. FEMA 306: Evaluation of earthquake damage concrete and masonry wall buildings, Basic Procedures Manual, Washington, DC, 1998.

[35] ABNT. ASSOCIAÇÃO BRASILEIRA DE NORMAS TÉCNICAS. NBR 15270-1: Blocos cerâmicos para alvenaria de vedação. Rio de Janeiro, ABNT, 2005.

[36] ABNT. ASSOCIAÇÃO BRASILEIRA DE NORMAS TÉCNICAS. NBR 15812-1: Alvenaria estrutural - Blocos cerâmicos. Parte 1: Projetos. Rio de Janeiro, ABNT, 2010. 